\title{
Study on the Strategy of Logistics Management Talent Development in Shandong Province
}

\author{
Jinhua Li \\ Yantai Nanshan University \\ Longkou, China 265713
}

\author{
Ping Wang \\ Yantai Nanshan University \\ Longkou, China 265713
}

\author{
Xiuli Tan \\ Yantai Nanshan University \\ Longkou, China 265713
}

\begin{abstract}
High-quality logistics management personnel is an important factor in the development of modern logistics. In recent years, as the rapid development of the economy and the logistics industry in Shandong Province, the provincial government attaches great importance to development of the logistics management of human resources, but there is a gap between the current situation of Shandong Province logistics management talent resources and the construction of large logistics for the logistics management of human resources. Based on this analysis of the status quo of logistics management of human resources in Shandong province, we analyzed the problems in its development, and then discussed the countermeasures of logistics personnel development in Shandong Province by referencing the experience of developed countries on talent development.
\end{abstract}

Keywords-Shandong Province; logistics management talent; development strategy

\section{INTRODUCTION}

The development of the logistics industry in Shandong province is the construction of China's eastern coastal areas and the Bohai Bay is an important part of the logistics circle. Meanwhile, as a demonstration base of China-ROK FTA, Shandong Province will accelerate economic development and industrial restructuring process, and promote the development of the province's logistics industry and logistics management talent needs. However, the development status of logistics management of human resources in Shandong Province with its large logistics construction still lags behind the requirements for logistics management of human resources.

\section{REVIEW OF THE LITERATURE}

At present, scholars have conducted a tentative research on regional logistics personnel training. Yanfang Luo(2009) analyzed the students' future employment prospects and put forward their own solutions from the college admissions, enrollment level, enrollment scale etc, By 2008 enrollment of Shandong Province logistics professional situation[1]. Lei Jiang(2010) analyzed the needs of logistics personnel problems and the next few years the number of logistics

[Foundation Project]Shandong Province Education Science "Twelfth Five Year Plan" key topic "Study on the construction of characteristic disciplines in private colleges and Universities Based on regional development"2013GZ061 personnel to market needs analysis in Shandong Province, and finally focuses on countermeasures logistics personnel development strategy[2]. Hua Zhao(2011) analysis the logistics of Shandong Province talent market supply and demand situation, logistics talent development in the presence of various problems, find out the root, from theory to practice, especially the research and put forward the Countermeasures of Shandong Province logistics talent development strategy[3]. Lianwei Li(2015) analyzed the urgency of Shandong Province agricultural products cold chain logistics personnel training and put forward some feasible countermeasures[4].In summary, scholars had conducted a lot of research on regional logistics personnel and has achieved some results, but the research strategy of Shandong Province logistics management talent development is still relatively scarce, and further research is needed.

\section{THE Status ANALYSis OF Logistics MANAGEMENT TALENTS IN SHANDONG PROVINCE}

\section{A. The Status of Logistics Management Talents in Shandong Province}

Since the 12th five-year plan, the logistics industry has developed rapidly and stably in Shandong province. In 2014, the total social logistics of Shandong province was 18.55 trillion yuan, grew by $8.16 \%$ over the same period of the previous year; the value of logistics industry has added 385.2 billion yuan, accounting for $6.5 \%$ of the provincial GDP and $14.9 \%$ of the tertiary industrial output-value; and the investment in fixed assets 419.81 billion yuan, with a year-onyear growth of $16 \%$, accounting for $10.1 \%$ of the province. The province's total social logistics costs 963.17 billion yuan, and the ratio of total social logistics costs and gross regional product is $16.2 \%$. The province's various modes of transport in terms of the amount of transmission of goods is 2.648 billion tons, having played an important supporting role in safeguarding of the economic development. The amount of province's logistics enterprises reached more than 22,000, of which 836 are key logistics enterprises. the province is now operational logistics park 339. There are 339 logistics park operating in Shandong province. 6 logistics companies are 
rated as the national logistics industry advanced collectives, and 64 logistics enterprises was named "Shandong Service Brand". A group of professional logistics enterprises grow rapidly, forming a logistics industry group with distinct characteristics constructed by various ownership, operating scales and service models, stimulating the social employment, promoting the regional economic development. The logistics infrastructures are improved constantly. The transportation of railways, highways, harbors, inland waterways, aviation, pipeline radiates in all directions. The highway mileage is 259,500 kilometers, of which the expressway is $5108 \mathrm{~km}$. There are 540 coastal ports productive berths, and the annual throughput is 1.286 billion tons; the railway operating mileage is $5110 \mathrm{~km}$, and there are 431 railway lines; the number of civil airports is 8 , and there are 368 routes, of which there are 41 international and regional routes, 327 domestic routes; the length of oil and gas pipelines is 10,281 kilometers, and 9.24 billion square of natural gas, 50 million tons of crude oil and 8.8 million tons of refined oil are transported annually. The logistics of trading and agriculture is expanding. In 2014, the number of Shandong province's wholesale and retail enterprises above designated size is 16800 , including 139 chain headquarters, 1.1 million chain stores, and 148 large above-scale enterprise distribution centers. With the logistcs of postal services, supply and marketing cooperatives as the backbone enterprises, 26000 three rural service stations are established in Shandong province, and more than 100,000 various stores, creating conditions to promote the province's industrial production to the countryside and two-way logistics system of agricultural products into the city. Electricity supplier logistics and express industry developed rapidly. In 2014, the province's companies and branches qualified with the express delivery business qualification reached 1,600, with express delivery business volume being 447 million, with a year-on-year growth of $42.42 \%$; the operating income is 6.701 billion yuan, grew by $22.96 \%$ over the same period of the previous year. The province's e-commerce transactions amount to 1.3 trillion yuan, with the growth rate of more than $25 \%$. More than 55 percent of industrial enterprises above designated size adopt e-commerce for procurement and marketing. The online enterprises of "Shandong Good Product" network platform reach 15,671 , leading companies to complete turnover of 50.9 billion yuan. All these illustrates Shandong province has become an important logistics distribution hub which is sea and air all-round, multi-level and multi-functional.

Faced with the rapid development of the logistics industry, the logistics management talent supply in Shandong province is limited, particularly for logistics management talents still remaining in the exploratory stage. Because of the late start of logistics education, although some college institutions have set up logistics management major and direction, a considerable parts evolve from traditional materials management, material economy, traffic engineering and other major. The knowledge structure cannot meet the needs of modern logistics industry development. According to the research, in Shandong province the existing logistics management talents education possess some shortages, such as, higher academic education but smallscale, low level of education, logistics management personnel structure irrational, a serious lack of high-level personnel, logistics and low quality of vocational training inadequate.

\section{B. The Existing Development Problems of Logistics Management Talents in Shandong Province}

1) The college logistics management talents education standard suited not to business needs: There is a lack of adequate communication and understanding between universities and companies. Although many colleges and universities are studying the combining problem of industry, academia and research, a few are truly implemented. There is little communication between the setting of teaching programs training objectives, curriculum and practical aspects in universities and the companies. Especially the contact between the advanced occupational education and the companies should be the most dense, but most colleges and universities are performing mere formally. Many colleges and universities are running in the "behind closed doors" state, which makes it difficult to cultivate our logistics talents really adapt to the actual needs of the society and businesses.

2) A deep gap between the concept and business reality : As the modernization, mechanization, degree of intelligence and information of enterprises are not relatively high and the traditional logistics activities in our social and economic life have occupied a large proportion, it leads the people to have a lack of knowledge about the function of logistics. All these lead to a vicious circle. The number of trained talents engaged in logistics companies activities is a few. The wages of grassroots logistics activities staff are not high, and the low qualified employees have difficult to introduced the concept of modern logistics to daily production activities, which forms a misunderstanding constraining on China's development of logistics enterprises.

3) The working environment of Logistics industry can not satisfy the employees: As China's logistics industry is laborintensive industries, at present the quality level and income of the logistics employees are general low. The traditional logistics enterprises lack of effective incentive mechanism, flexible employment mechanism and employees can not enjoy more training, leading to the professional logistics talents to give up and turn to the other industries. Most of China's logistics industry are transformed from the traditional logistics sectors engaged in the transportation and warehousing. There is a big flaw in the hardware and software environment and the concept. Because of social overheating logistics, the graduates do not have a clear understanding about the basic situation of China's logistics. During working, the graduates feel a deep gap between their dreams and reality in their mind, thinking that is not the modern logistics and losing enthusiasm for the work and passion of innovation.

\section{The TALENT DEVElopment EXPERIENCE OF DEVELOPED COUNTRIES}

The talents development of the United States attaches great importance to human resources continuing education. A 
college of further education or department of engineer continuing education is attached to the USA's universities or colleges, serving the technical talents in regional companies, providing credit courses and a variety of learning opportunities.

The talents development of Japan attaches great importance to the combination of education and markets. The degree of participation of Japanese companies in the development of human resources is much higher than the average countries, mainly due to heavy personal qualities and special skills of the selection standards entrenched Japanese companies. In addition to self-evaluation, the Japanese universities adopt many third-party evaluation out of the school, and publish the results of the evaluation in the community. In addition, the university also actively promotes cooperation with industries.

The talents development of German attaches great importance to college education. German universities focus on scientific research, pay attention to theoretical study, possessing profound culture. The flow institution of professors ensures that the various universities' levels are similar and develop balanced. In addition, Germany is also trying to create a favorable policy environment.

\section{The Logistics Management Talent DeVelopment STRATEGY OF SHANDONG PROVINCE}

\section{A. Strengthen the Top-level Design of Government Guarantee Mechanism}

The relevant departments of Shandong Province is investigating the establishment of priority to the development of education investment mechanism and ensure that the growth rate of financial education investment is higher than regular financial investment.

We should rely on the provincial, City Talent Exchange Center to establish and improve the logistics management on the integrity of the database file, and take advantage of computer network technology to get the implementation of network management.

What's more, establishing and improving the logistics management personnel credit file sharing mechanism, achieving the electronic access and retrieval functions and providing reference information for the enterprise recruitment is essential.

\section{B. Build Training Platform for Enterprise Application Personnel}

Recently, most students majoring in logistics management choose to work in enterprise. Therefore, universities in Shandong should consider the school orientation, the business needs of logistics management personnel. And then we can adjust the teaching ideas of logistics management curriculum, and train logistics management personnel to meet the business needs. To build enterprise application type personnel training platform is based on ability cultivation of talent development mode, which is different from the traditional teaching methods, which mainly focus on from training students comprehensive ability of logistics management and innovation perspective to enhance students' employment.

\section{Explore the Application of Management Personnel and Train New Model}

With the development of economy and society in Shandong, the needs of industry for the logistics management talent demand present the multiplex tendency. How to change the traditional way of training of logistics management personnel, to adapt to the development needs of the times of logistics management talent diversification, has become an important task of education reform in Shandong .we should consider the situation of each province, learn from developed countries (such as Germany dual system) talent training mode, take innovation in method about the application management personnel in Colleges in Shandong Province.

\section{Improve the Industry Association Training Service System}

We should integrate education and training resources in logistics management between universities and various social training institutions, form a wide coverage, multi level logistics management education and training network. Improving self-discipline, supervision and management system of logistics training industry association, strengthening selfdiscipline in training industry associations, promoting each logistics training institutions to self regulate, self management as the goal, establishing industry training and qualification certification system is also important.

\section{E. Explore the University Personnel Training and Enterprise Talent Demand Linkage Mechanism}

The development of Shandong Province logistics management personnel should explore the university personnel training and enterprise talent demand linkage mechanism. Close cooperation between school and enterprise, can provide a real professional environment for teaching .It's helpful to solve the lack of school training station, the lack of training equipment and resources, the lack of practical experience of the teacher and many other practical problems, making colleges and universities understand the true social needs much further. Colleges take advantage of various training platform for students to experience logistics enterprise operation process by themselves. In order to improve students' vocational ability as the basic, and lay a solid foundation for the development of school enterprise cooperation, train applied personnel of logistics management for the advanced teaching means, the practice teaching of the students should follow the development of the logistics industry demand.

\section{CONCLUSION}

The research and development of Shandong Province logistics management talent, is the need to adapt to the economic development of Shandong Province, to meet the transformation and upgrading of the logistics industry of Shandong province. Overall, Shandong Province logistics management talent development strategies include strengthening government guarantee mechanism of top-level design, building enterprise application type talents training 
platform, exploring the college application management personnel training mode, improving industry association training service system, exploring the university personnel training and enterprise talent demand linkage mechanism.

\section{REFERENCES}

[1] Yanfang Luo.Analysis of the status quo and Prospect of employment of logistics talents training in Shandong Province[J].Market Modernization, 2009 (9): 147-148.

[2] Lei Jiang.Based on the Grey System Theory of Shandong Logistics Talent Demand Analysis[D].Shandong:Shandong University, 2010.

[3] Hua Zhao.The Logistics Talents Development Strategy and Research of Shandong Province[J].Logistics Sci-Tech,2011 (5): 126-128.

[4] Lianwei Li. Study on the culture of Shandong Province agricultural products cold chain logistics personnel based on scientific and technological innovation[J]. Science \& Technology Review,2015 (2): 130. 